http://efm.vsau.org/

DOI: 10.37128/2411-4413-2020-4-12

\author{
ФОРМУВАННЯ \\ СИСТЕМИ ОБЛІКУ \\ ОКРЕМИХ ВИДІВ \\ ДІЯЛЬНОСТІ НА РІВНІ \\ ПІДПРИЕМСТВА
}

КОВАЛЬ Л.В., кандидат економічних наук, доцент кафедри бухгалтерського обліку, Вінницький національний аграрний університет (м. Вінниця)

У статті досліджено особливості формування облікової політики окремих видів діяльності. Зокрема, окреслено визначення зовнішньоекономічної діяльності та встановлено основні ії види. Окрім иьього в статті наведено статистичні дані щзодо динаміки експортноімпортних операчій вітчизняних підприємств у період з 2013 по 2019 роки. Виокремлено специфічні особливості облікового відображення зовнішньоекономічних операцій та їхній вплив на формування облікової політики суб'єкта господарювання. Установлено, щуо для формування облікової політики зовнішньоекономічних операцій важливе значення має прочес організації обліку такої діяльності, у зв'язку з чим було представлено алгоритм формування інформачї аналітичного і синтетичного обліку експортно-імпортних операцій. Наведено приклад Робочого плану рахунків зовнішньоекономічної діяльності як частини організачійнотехнічної складової облікової політики та окреслено напрямки його формування: за видами іноземної валюти; за географічним розташуванням контрагента; за видом обраної формули Інкотермс відповідно до моменту передачі ризиків та зобов 'язань; за видами експортованого чи імпортованого товару; за видами монетарної статті; за іншими ознаками. Визначено, щзо в умовах сьогодення автоматизаџія облікового процесу на будь-якому підприємстві сприяє зменшенню витрат часу на виконання облікової роботи працівниками бухгалтерії та дозволяє своєчасно забезпечити управлінський персонал суб'єкта господарювання повною та достовірною інформацією. У зв'язку з ичим при здійсненні зовнішньоекономічної діяльності запропоновано використовувати автоматизовану форму ведення обліку з подальшим відображенням такої інформації в Наказі про облікову політику підприємства. Окреслено елементи облікової політики зовнішньоекономічних операцій з урахуванням особливостей імпорту. На основі проведеного дослідження зроблено відповідні висновки та вказано напрямки подальшого дослідження і причини його необхідності.

Ключові слова: облікова політика, нормативно-правова база, зовнішньоекономічна діяльність, експорт, імпорт, валюта.

Рис.: 3. Табл.: 1. Літ.: 9.

\title{
FORMATION OF THE SYSTEM OF ACCOUNTING OF CERTAIN ACTIVITIES AT THE LEVEL OF THE ENTERPRISE
}

\author{
KOVAL Lyubov, \\ Candidate of Economic Sciences, \\ Associate Professor of Accounting Department, \\ Vinnitsa National Agrarian University \\ (Vinnytsia)
}

The article examines the features of the formation of accounting policies for certain activities. In particular, the definition of foreign economic activity is outlined and its main types are established. 
In addition, the article presents statistical data on the dynamics of export-import operations of domestic enterprises in the period from 2013 to 2019. The specific features of the accounting reflection of foreign economic transactions, and their impact on the formation of the accounting policy of the business entity. It is established that the process of organizing the accounting of such activities is important for the formation of the accounting policy of foreign economic transactions. In this regard, the algorithm for generating information of analytical and synthetic accounting of export-import operations was presented. An example of the Working Plan of accounts of foreign economic activity as a part of organizational and technical component of accounting policy is given, and the directions of its formation are outlined: by types of foreign currency; by geographical location of the counterparty; according to the type of the selected Incoterms formula according to the moment of transfer of risks and obligations; by types of exported or imported goods; by types of monetary article; on other grounds. It is established that in today's conditions, the automation of the accounting process at any company helps to reduce the time spent on accounting work by accounting staff and allows you to provide timely management staff of the entity with complete and accurate information. In this regard, in carrying out foreign economic activity, it is proposed to use an automated form of accounting, with subsequent reflection of such information in the Order on the accounting policy of the enterprise. The elements of the accounting policy of foreign economic transactions are outlined, taking into account the peculiarities of imports. On the basis of the conducted research the corresponding conclusions are made and the directions of the further research and the reasons of its necessity are specified.

import, currency.

Keywords: accounting policy, regulatory framework, foreign economic activity, export,

Fig.: 3. Tab.: 1. Lit.: 9.

\title{
ФОРМИРОВАНИЕ СИСТЕМЫ УЧЕТА ОТДЕЛЬНЫХ ВИДОВ ДЕЯТЕЛЬНОСТИ НА УРОВНЕ ПРЕДПРИЯТИЯ
}

\author{
КОВАЛЬ Л. В, \\ кандидат экономических наук, доцент \\ кафедры бухгалтерского учета, \\ Винницкий национальный аграрный университет
} (2. Винница)

В статье исследованы особенности формирования учетной политики отдельных видов деятельности. B частности обозначены определения внешнеэкономической деятельности и установлены основные ее виды. Кроме этого в статье приведены статистические данные по динамике экспортно-импортных операций отечественных предприятий в период с 2013 по 2019 годы.

Выделены специфические особенности учетной отображения внешнеэкономических операций и их влияние на формирование учетной политики предприятия. Установлено, что для формирования учетной политики внешнеэкономических операций важное значение имеет процесс организачии учета такой деятельности. В связи с чем было представлено алгоритм формирования информации аналитического и синтетического учета экспортно-импортных операций. Приведен пример Рабочего плана счетов внешнеэкономической деятельности, как части организачионно-технической составляющей учетной политики, и намечень направления его формирования: по видам иностранной валюты; по географическому расположению контрагента по виду выбранной формуль Инкотермс до момента передачи рисков и обязательств; по видам экспортируемого или импортируемого товара; по видам монетарной статьи; по другим признакам. Установлено, что в сегодняшних условиях автоматизачия учетного прочесса на любом предприятии способствует уменьшению затрат времени на выполнение учетной работь работниками бухгалтерии и позволяет 
своевременно обеспечить управленческий персонал предприятия полной и достоверной информацией. В связи с этим при осуществлении внешнеэкономической деятельности предложено использовать автоматизированную форму ведения учета, с последующим отражением такой информациии в Приказе об учетной политике предприятия. Определены элементы учетной политики внешнеэкономических операций, с учетом особенностей импорта. На основе проведенного исследования сделаны соответствующие выводы и указаны направления дальнейшего исследования и причины его необходимости.

Ключевые слова: учетная политика, нормативно-правовая база, внешнеэкономическая деятельность, экспорт, импорт, валюта.

Рис.: 3. Табл.: 1. Лит.: 9.

Постановка проблеми. В умовах сучасних глобальних викликів за рахунок безперервних інновацій та зусиль, спрямованих на підвищення продуктивності, налагодження переробки та формування додавання вартості, використання сучасних технологій та створення інфраструктури вітчизняним товаровиробникам вдається виходити на зовнішні ринки [7].

Здійснення господарської діяльності передбачає, що частина господарських зв'язків здійснюється за участю іноземних контрагентів. Оскільки в цьому разі необхідно враховувати вимоги чинного законодавства щонайменше двох країн, то питання обліку зовнішньоекономічних операцій завжди знаходились під пильною увагою як практиків, так і науковців. У цих умовах важлива роль належить обліковій політиці підприємств. Оскільки облікова політика повинна включати порядок відображення в обліку всіх аспектів господарського життя підприємства, то в умовах пожвавлення зовнішньоекономічної діяльності при формуванні облікової політики суб'єкта господарювання, що здійснює таку діяльність, необхідне формування додаткових елементів облікової політики, які враховують специфіку цієї діяльності для потреб управління та формування достовірних показників бухгалтерської та податкової звітності у частині операцій, пов'язаних 3 експортом, імпортом, іноземними інвестиціями [1].

Аналіз останніх досліджень і публікацій. Особливостям функціонування підприємства в умовах здійснення зовнішньоекономічної діяльності (надалі ЗЕД) присвячено достатньо уваги з боку як теоретиків, так і практиків. Деякі 3 них розглядали це питання крізь призму облікового відображення: Венцель В.Т. [5], Свдокимов В.В. [5], Івасів Б.С. [6], Киш Л.М. [7], Коваль О.В. [8], Оляднічук Н.В. [4], Прийдун Л.М. [6], Підлубна О.Д. [4], Рудан В.Я. [6], Смірнова І.В. [1], Смірнова Н.В. [1] та ін.

Однак питання формування облікової політики зовнішньоекономічної діяльності розкрито не повною мірою та потребує грунтовного дослідження. Це і спричинило вибір теми дослідження.

Мета статті. Метою статті $є$ вивчення процесу формування облікової політики підприємства в умовах здійснення ЗЕД, виявлення проблемних аспектів та внесення пропозицій щодо їх усунення.

Виклад основного матеріалу. Розробці методичних підходів до формування облікової політики зовнішньоекономічних операцій має передувати 
дослідження та структуризація зовнішньоекономічної діяльності загалом [1].

Згідно із Законом України «Про зовнішньоекономічну діяльність» зовнішньоекономічна діяльність (ЗЕД) - це діяльність суб'єктів господарської діяльності України та іноземних суб'єктів господарської діяльності, а також діяльність державних замовників 3 оборонного замовлення у випадках, визначених законами України, побудована на взаємовідносинах між ними, що має місце як на території України, так і за їі межами [2].

До основних видів ЗЕД належать:

- експорт та імпорт товарів, капіталів та робочої сили;

- надання суб'єктами зовнішньоекономічної діяльності України послуг іноземним суб'єктам господарської діяльності;

- надання послуг іноземними суб'єктами господарської діяльності суб'єктам зовнішньоекономічної діяльності України;

- міжнародні фінансові операції та операції з цінними паперами у випадках, передбачених законами України;

- кредитні та розрахункові операції між суб'єктами зовнішньоекономічної діяльності та іноземними суб'єктами господарської діяльності;

- спільна підприємницька діяльність між суб'єктами зовнішньоекономічної діяльності та іноземними суб'єктами господарської діяльності, що включає створення спільних підприємств різних видів і форм, проведення спільних господарських операцій та спільне володіння майном як на території України, так і за ії межами;

- організація та здійснення оптової, консигнаційної та роздрібної торгівлі на території України за іноземну валюту у передбачених законами України випадках;

- товарообмінні (бартерні) операції та інша діяльність, побудована на формах зустрічної торгівлі між суб'єктами зовнішньоекономічної діяльності та іноземними суб'єктами господарської діяльності;

- орендні, у тому числі лізингові, операції між суб'єктами зовнішньоекономічної діяльності та іноземними суб'єктами господарської діяльності;

- операції з придбання, продажу та обміну валюти на валютних аукціонах, валютних біржах та на міжбанківському валютному ринку;

- інші види зовнішньоекономічної діяльності, не заборонені прямо і у виключній формі законами України [2].

Як видно з поділу ЗЕД на види, іï основу складають саме експортноімпортні операції.

Динаміку ЗЕД вітчизняних підприємств, а саме експортно-імпортних операцій, зображено на рис.1.

Потрібно також зазначити, що структурною одиницею зовнішньоекономічної діяльності є зовнішньоекономічна операція.

Зовнішньоекономічна операція - це комплекс дій контрагентів різних країн з підготовки, укладання і виконання торговельної, інвестиційної чи іншої угоди економічного характеру [1]. 
http://efm.vsau.org/

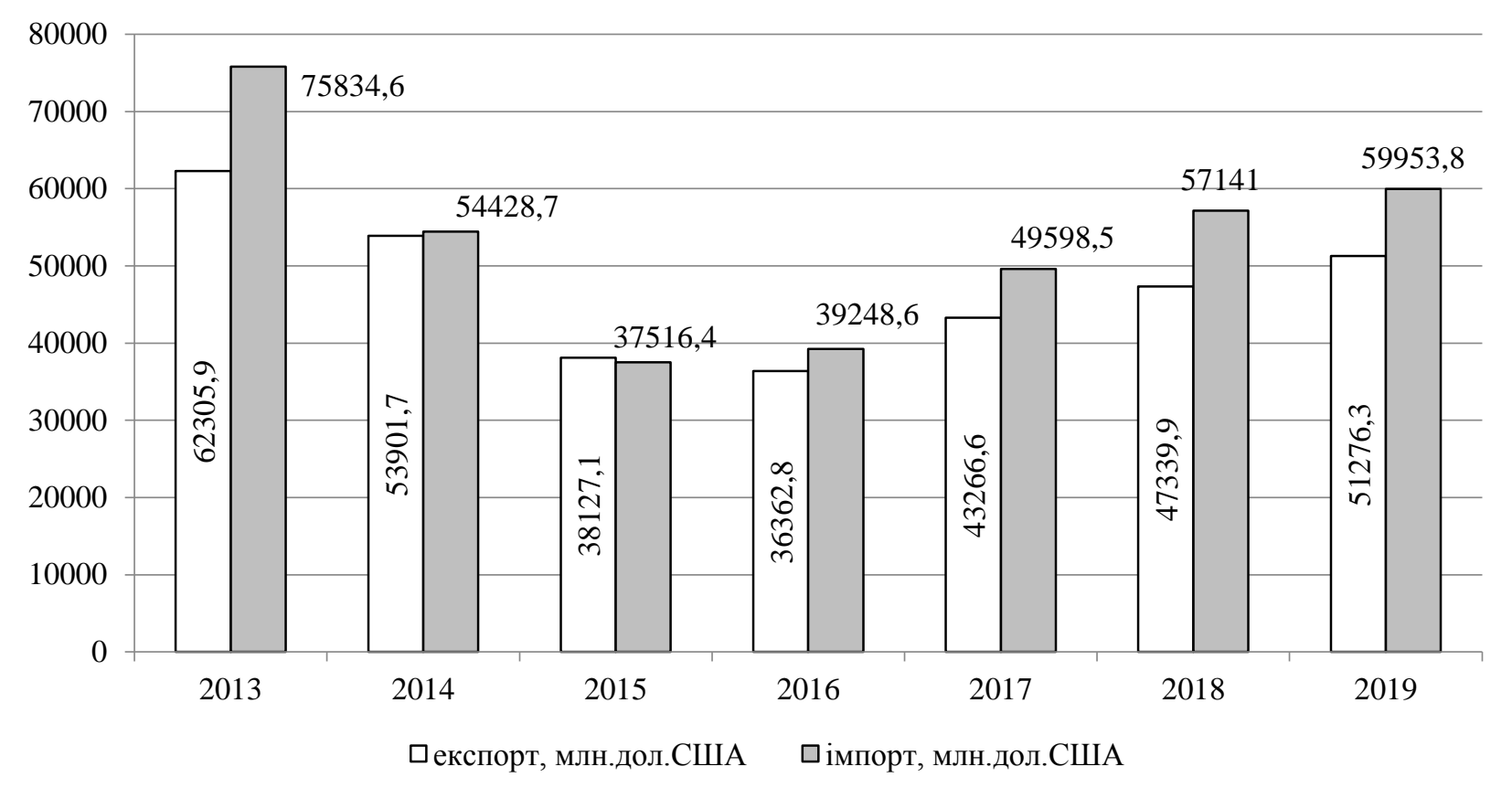

Рис.1. Динаміка експортно-імпортних операцій вітчизняних підприсмств

Джерело: сформовано автором на основі [3]

Усі зовнішньоекономічні операції для облікових цілей поділяються на:

- експортно-імпортні операції з обліку товарів та послуг;

- облікові операції щодо руху капіталу.

Експортно-імпортні операції з обліку товарів та послуг включають операції з імпорту, експорту, продажу і придбання ліцензій, реімпорту, реекспорту, обміну (бартеру), «ноу-хау», технічної документації, фінансового лізингу імпортного устаткування. Поряд із цим облікові операції щодо руху капіталу включають одержання фінансових (банківських) кредитів, придбання й продаж цінних паперів, тобто $€$ фактично обліком інвестицій в умовах здійснення ЗЕД.

Специфіка обліку операцій ЗЕД зумовлена такими особливостями:

- розрахунки, платежі з іноземними контрагентами та митними органами здійснюються в національній та іноземній валюті;

- контрагентами (покупцями, постачальниками, підрядниками, замовниками тощо) $є$ вітчизняні й іноземні фірми;

- майно, ТМЦ знаходяться в дорозі, складуються і зберігаються на території різних держав;

- витрати, пов'язані із зовнішньоторговельними операціями здійснюються як у межах України, так і на території іноземних держав з урахуванням їх розподілу між контрагентами відповідно до умов постачання системи Інкотермс [1].

Для формування облікової політики зовнішньоекономічних операцій важливе значення має процес організації обліку такої діяльності. Схематично він зображений на рис. 2. 
ПЕРВИННІ ДОКУМЕНТИ (ТОВАРОСУПРОВІДНІ)

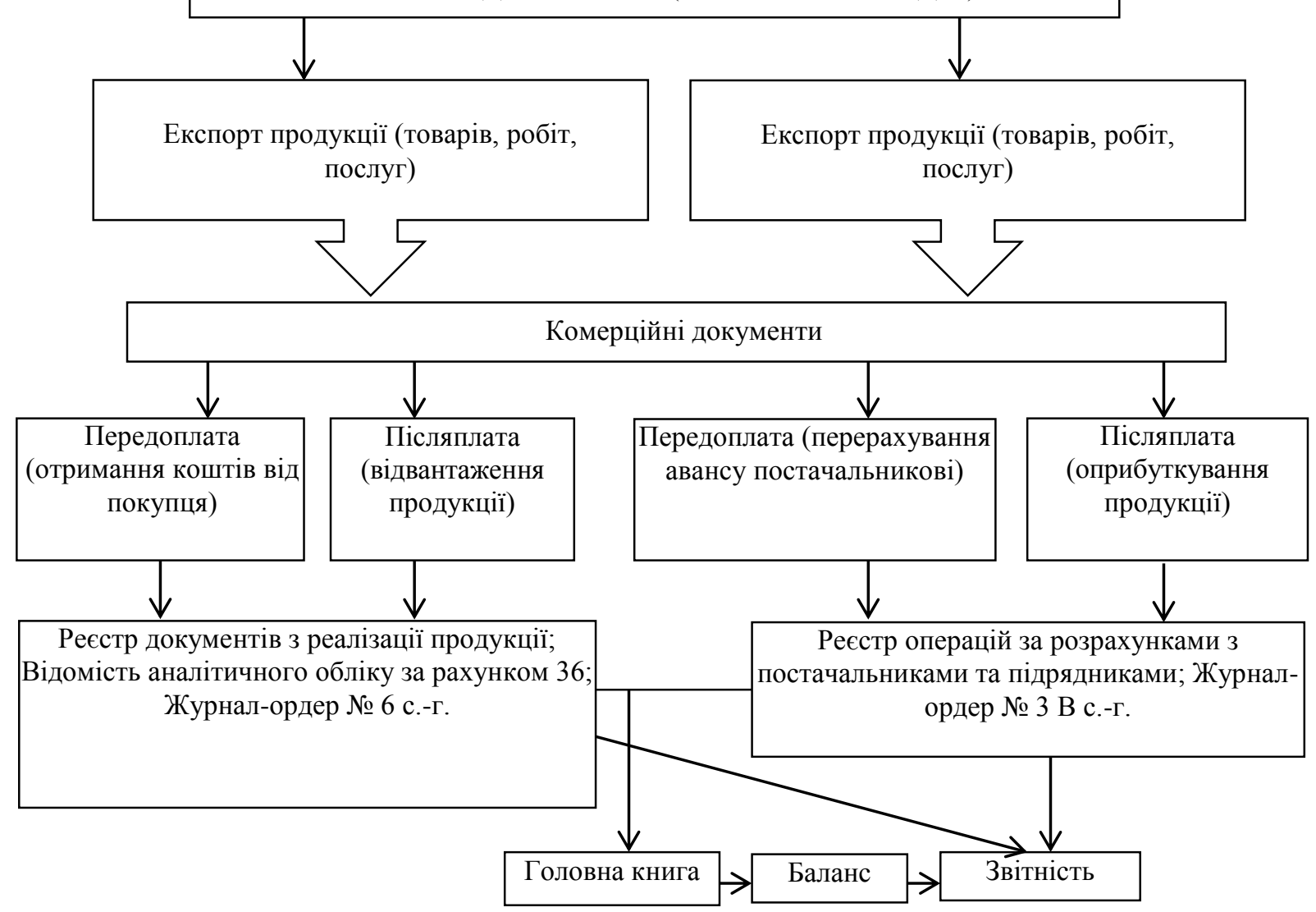

Рuc. 2. Алгоритм формування інформації аналітичного i синтетичного обліку експортно-імпортних операцій

Джерело: сформовано автором на основі [4]

Як видно 3 рисунка, початок формування інформації про зовнішньоекономічні операції відбувається у первинних документах.

Підставою для обліку імпортно-експортних операцій $\epsilon$ договірні, супровідні, дозвільні, митні, страхові, розрахунково-платіжні та претензійні документи. 3 огляду на вище викладене доцільно впорядкувати за суттю документи первинного обліку експортно-імпортних операцій (рис. 3).

Для здійснення зовнішньоекономічних операцій необхідно укласти договір (контракт) 3 іноземним контрагентом, що укладається в результаті домовленостей. Від умов зазначених у контракті залежить ведення бухгалтерського обліку.

Постачання товару з однієї країни до іншої пов'язане з витратами, ризиком і здійсненням низки технічних та адміністративних функцій. Ці питання торгові партнери погоджують в зовнішньоекономічному контракті шляхом застосування «базових умов» Інкотермсу, що зводять до мінімуму непорозуміння та спори щодо таких трьох аспектів угоди: хто, від якого і до якого пункту доставки здійснює постачання товару та несе витрати, відповідає за можливі ризики; у який момент постачання ризик втрати товару переходить від продавця до покупця; хто здійснює митне оформлення (митну чистку) товару" [6]. 


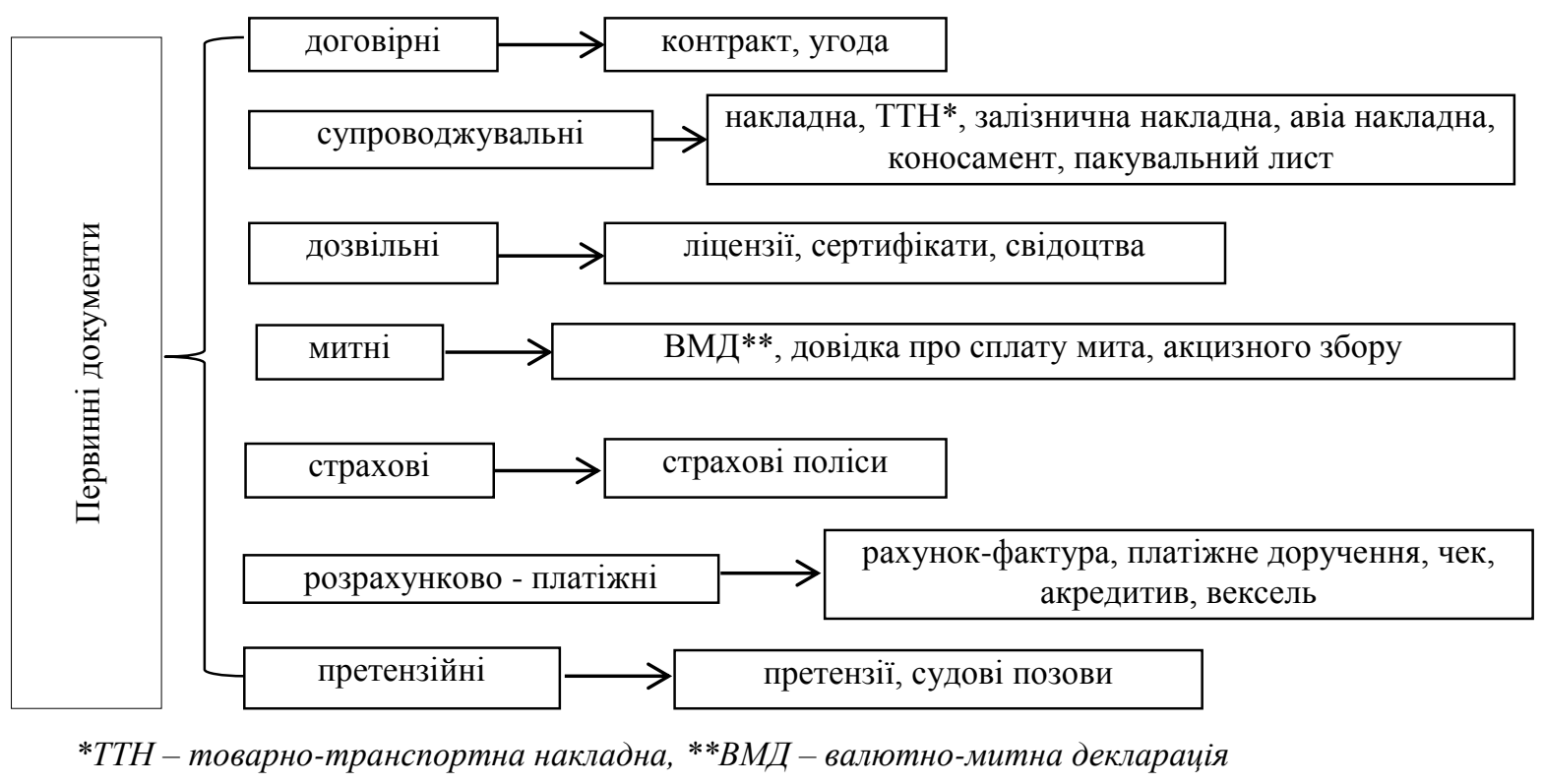

Рис. 3. Групувальні ознаки первинних документів експортноімпортних операцій

Джерело: сформовано автором на основі [4]

На основі укладених контрактів чи угод відбувається безпосередньо виконання умов договірних документів. Підприємство здійснює передоплату та післяплату. При чому ними можуть бути як перерахування коштів, так і рух товару, продукції (робіт, послуг).

Для належного відображення таких операцій в обліку на підприємстві повинен бути розроблений Робочий план рахунків, один 3 можливих варіантів якого наведено в таблиці 1.

Потрібно зауважити, що розробка Робочого плану рахунків може здійснюватися за: видами іноземної валюти; географічним розташуванням контрагента; видом обраної формули Інкотермс відповідно до моменту передачі ризиків та зобов'язань; видами експортованого чи імпортованого товару; видами монетарної статті; іншими ознаками.

Облік товарів (робіт, послуг) здійснюється на момент ввезення в межі або вивезення за межі економічної території країни. Зовнішньоекономічна діяльність України щодо ввезення та вивезення товарів методом водного, залізничного, автомобільного чи повітряного транспортування обліковується за датою оформлення митної декларації. При переміщенні товару трубопроводом (нафта, нафтопродукти тощо), облік здійснюється за датою останнього транспортного документу; для природного газу - за датою останнього дня місяця, у якому здійснювалося митне оформлення товару. Моментом експорту/імпорту товарів, що не підлягають митному декларуванню, є дата оформлення приймальноздавального акту або дата платіжного документа [3].

У сьогоднішніх умовах господарювання автоматизація облікового процесу на будь-якому підприємстві дає можливість суттєво зменшити витрати часу на виконання бухгалтерської роботи працівниками бухгалтерії та своєчасно 
забезпечити керівництво підприємства необхідною інформацією [8]. Тому при здійсненні зовнішньоекономічної діяльності доцільно використовувати автоматизовану форму ведення обліку, про що варто зазначити в Наказі про облікову політику підприємства.

Таблиия 1

Рахунки бухгалтерського обліку експортно-імпортних операцій

\begin{tabular}{|c|c|c|c|}
\hline & $\begin{array}{c}\text { Синтетичні рахунки } \\
\text { (рахунки першого порядку) }\end{array}$ & & $\begin{array}{c}\text { Субрахунки } \\
\text { (рахунки другого порядку) }\end{array}$ \\
\hline Код & Назва & Код & Назва \\
\hline \multirow{4}{*}{29} & \multirow{4}{*}{$\begin{array}{c}\text { Товари } \\
\text { за експортно-імпортними } \\
\text { операціями }\end{array}$} & 291 & Товари відвантажені (експортовані) \\
\hline & & 292 & Товари придбані (імпортовані) \\
\hline & & 293 & Товари відвантажені (експортовані без вивезення) \\
\hline & & 294 & Товари придбані (імпортовані без ввезення) \\
\hline 36 & $\begin{array}{c}\text { Розрахунки з покупцями } \\
\text { та замовниками } \\
\end{array}$ & 362 & Розрахунки з іноземними покупцями \\
\hline \multirow{3}{*}{37} & \multirow{3}{*}{$\begin{array}{c}\text { Розрахунки } \\
\text { з різними дебіторами }\end{array}$} & 3712 & Розрахунки за виданими авансами в іноземній валюті \\
\hline & & 3742 & Розрахунки за претензіями в іноземній валюті \\
\hline & & 3772 & Розрахунки з іншими дебіторами в іноземній валюті \\
\hline 63 & $\begin{array}{c}\text { Розрахунки з постачальниками } \\
\text { та підрядниками }\end{array}$ & 632 & Розрахунки з іноземними постачальниками \\
\hline \multirow{3}{*}{64} & \multirow{3}{*}{$\begin{array}{c}\text { Розрахунки } \\
\text { за податками й платежами }\end{array}$} & 6411 & Розрахунки за податком на додану вартість \\
\hline & & 6412 & Розрахунки за акцизним податком \\
\hline & & 6421 & Розрахунки за митом \\
\hline \multirow{2}{*}{68} & \multirow{2}{*}{$\begin{array}{c}\text { Розрахунки } \\
\text { за іншими операціями }\end{array}$} & 6812 & Розрахунки за авансами одержаними в іноземній валюті \\
\hline & & 6852 & Розрахунки з іншими кредиторами в іноземній валюті \\
\hline \multirow{3}{*}{70} & \multirow{3}{*}{ Доходи від реалізації } & 7012 & Дохід від реалізації експортної готової продукції \\
\hline & & 7022 & Дохід від реалізації експортних товарів \\
\hline & & 7032 & Дохід від реалізації експортних робіт і послуг \\
\hline 71 & Інший операційний дохід & 714 & Дохід від операційної курсової різниці \\
\hline 74 & Інші доходи & 744 & Дохід від не операційної курсової різниці \\
\hline 79 & Фінансові результати & 7912 & Фінансовий результат від експортних операцій \\
\hline \multirow{3}{*}{90} & \multirow{3}{*}{ Собівартість реалізації } & 9011 & Собівартість реалізованої експортної готової продукції \\
\hline & & 9022 & Собівартість реалізованих експортних товарів \\
\hline & & 9032 & Собівартість реалізованих експортних робіт і послуг \\
\hline 93 & Витрати на збут & 932 & Експортні витрати на збут \\
\hline 94 & Інші витрати операційної діяльності & 945 & Втрати від операційної курсової різниці \\
\hline 97 & Інші витрати & 974 & Втрати від не операційних курсових різниць \\
\hline \multirow{2}{*}{06} & \multirow{2}{*}{ Гарантії та забезпечення отримані } & 063 & Митна вартість імпортних товарів \\
\hline & & 064 & Облікова вартість імпортних товарів \\
\hline
\end{tabular}

Одним із видів зовнішньоекономічних операцій $є$ імпортні операції.

3 огляду на специфіку здійснення основними завданнями бухгалтерського обліку зовнішньоекономічних операцій є:

- перевірка правильності документального оформлення товарних та розрахункових операцій;

- дотримання вимог валютного та митного законодавства;

- формування достовірної інформації про рух імпортних товарів (купівля, зберігання, реалізація);

- формування достовірної інформації про курсові різниці [1].

Облік імпортних товарно-матеріальних цінностей ідентичний загальним вимогам обліку, за винятком деяких особливостей, зокрема:

- приймання імпортних товарів 3 обов'язковою участю експерта 
торговельно-промислової палати України із складанням приймального акту і акту експертизи. При виявленні нестачі або дефекту товарів складається рекламаційний акт;

- обов'язкове декларування експортно-імпортних товарів при перетині митного кордону України;

- відображення в обліку приймання товарів, що імпортуються, за датою вантажної митної декларації;

- необхідність відокремленого обліку імпортних товарів і розрахунків щодо їх придбання;

- організація аналітичного обліку за найменуваннями, кількістю товарів, обліковими партіями, контрактами, країнами та консигнаторами [1].

Виходячи з цього можна зробити висновок, що облікова політика в частині імпортних операцій в цілях бухгалтерського обліку має визначати такі складові:

- первісна оцінка товарів;

- облікова одиниця товарів;

- порядок проведення уцінки;

- облік транспортно-заготівельних витрат [1].

Окрім цього, при експортних операціях потрібно відобразити порядок визнання та оцінки іноземної валюти і порядок формування вартості експортної продукції.

Висновки. Організаційно-технічна складова облікової політики при здійсненні ЗЕД передбачає виокремлення інформації щодо: переліку використовуваних первинних документів за їх видами; обраної групи базових умов постачання відповідно до правил Інкотермс; застосовуваної форми ведення обліку (перевага надається автоматизованій); переліку рахунків Робочого плану рахунків, що формується з урахуванням використовуваних видів іноземної валюти; географічного розташування контрагента; виду обраної формули Інкотермс відповідно до моменту передачі ризиків та зобов'язань; видів експортованого чи імпортованого товару; виду монетарної статті; інших ознак.

Методична ж складова передбачає розкриття інформації щодо: первісної оцінки та облікової одиниці товарів, порядку проведення переоцінки, обліку ТЗВ, визнання та оцінки іноземної валюти, порядку формування вартості експортної продукції.

Не всі окреслені елементи облікової політики знаходять своє відображення в переліку методичних рекомендацій. Однак теоретичні дослідження та практичний досвід підтверджує їхню необхідність.

Варто також наголосити, що подальші дослідження 3 цієї тематики потрібно проводити періодично у зв'язку зі зміною законодавства 3 питань здійснення та ведення обліку ЗЕД.

\section{Список використаних джерел}

1. Смірнова І.В., Смірнова Н.В. Методичні підходи до формування облікової політики імпортних операцій. Наукові пращуі Кіровоградського національного технічного університету. Економічні науки. 2017. вип. 31 С.197- 
207.

2. Про зовнішньоекономічну діяльність: закон України від 16.04.1991 р. №959-XII. URL: https://zakon.rada.gov.ua/laws/show/959-12\#Text__дата звернення: 26.09.2020).

3. Зовнішня торгівля України: cmam. зб.: веб-сайт. URL: http://ukrstat.org/uk/druk/ publicat/Arhiv_u/10/Arch_ztu_zb.htm (дата звернення: 26.09.2020).

4. Оляднічук Н.В., Підлубна О.Д. Облік експортно-імпортних операцій. Облік і фінанси. 2017. № 1 (75). С. 48-56.

5. Свдокимов В.В., Венцель В.Т. Особливості організації бухгалтерського обліку на підприємстві, що здійснює зовнішньоекономічну діяльність. Науковий вісник Ужгородського університету. Серія Економіка. 2011. Випуск 2 (34). С. 270-275.

6. Івасів Б.С., Прийдун Л.М., Рудан В.Я. Міжнародні розрахунки та валютні операції: навч. посіб. Тернопіль: Вектор, 2013. 572 с.

7. Киш Л.М. Товарна структура експорту та імпорту сільськогосподарської та продовольчої продукції. Економіка, фінанси, менеджмент: актуальні питання науки і практики. 2019. № 9. С. 78-87.

8. Коваль О.В. Автоматизація бухгалтерського обліку на сільськогосподарському підприємстві в сучасних умовах. Економіка, фінанси, менеджмент: актуальні питання науки і практики. 2019. № 6. С. 136-141.

9. План рахунків бухгалтерського обліку активів, капіталу, зобов'язань і господарських операцій підприємств і організацій: затв. Наказом Мінфіну України від 09.12.2011 № 1591. URL: https://zakon.rada.gov.ua/laws/show/z155711\#Tеxt (дата звернення: 26.09.2020).

\section{References}

1. Smirnova, I.V. \& Smirnova, N.V. (2017). Metodychni pidkhody do formuvannia oblikovoi polityky importnykh operatsii [Methodical approaches to the formation of accounting policies for import operations]. Naukovi pratsi Kirovohradskoho natsionalnoho tekhnichnoho universytetu. Ekonomichni nauky Scientific works of Kirovograd National Technical University. Economic sciences, vyp. 31, 197-207.

2. Pro zovnishnoekonomichnu diialnist: zakon Ukrainy vid 16.04.1991 r. №959XII. [On foreign economic activity: the law of Ukraine from 16.04.1991 №959-XII]. (1991, 16.04). (n.d.). zakon.rada.gov.ua. URL: https://zakon.rada.gov.ua/laws/show/959-12\#Text [in Ukrainian].

3. Zovnishnia torhivlia Ukrainy: stat. zb. [Foreign trade of Ukraine: stat. Coll ] veb-sait. (n.d.). ukrstat.org. URL: http://ukrstat.org/uk/druk/ publicat/Arhiv_u/10/Arch_ztu_zb.htm [in Ukrainian].

4. Oliadnichuk, N.V. \&, Pidlubna O.D. (2017). Oblik eksportno-importnykh operatsii [Accounting for export-import transactions]. Oblik i finansy-Accounting and finance, 1(75), 48-56.

5. Yevdokymov, V.V. \& Ventsel ,V.T. (2011). Osoblyvosti orhanizatsii 
bukhhalterskoho obliku na pidpryiemstvi, shcho zdiisniuie zovnishnoekonomichnu diialnist [Features of the organization of accounting at the enterprise carrying out foreign economic activity]. Naukovyi visnyk Uzhhorodskoho universytetu. Seriia Ekonomika - Scientific Bulletin of Uzhhorod University. Economics series, Vypusk 2 (34), 270-275.

6. Ivasiv, B.S., Pryidun, L.M., Rudan, V.Ya. (2013). Mizhnarodni rozrakhunky ta valiutni operatsii [International settlements and currency transactions]. Ternopil: Vektor [in Ukrainian].

7. Kysh, L.M. (2019). Tovarna struktura eksportu ta importu silskohospodarskoi ta prodovolchoi produktsii [Commodity structure of exports and imports of agricultural and food products]. Ekonomika, finansy, menedzhment: aktualni pytannia nauky $i$ praktyky - Economy, finances, management: current issues of science and practice, 9, 78-87 [in Ukrainian].

8. Koval, O.V. (2019). Avtomatyzatsiia bukhhalterskoho obliku na silskohospodarskomu pidpryiemstvi $\mathrm{v}$ suchasnykh umovakh [Automation of accounting at an agricultural enterprise in modern conditions]. Ekonomika. Finansy. Menedzhment: aktualni pytannia nauky i praktyky - Economy. Finances. Management: current issues of science and practice, 6, 136-141 [in Ukrainian].

9. Plan rakhunkiv bukhhalterskoho obliku aktyviv, kapitalu, zobov'iazan i hospodarskykh operatsii pidpryiemstv i orhanizatsii: zatv. Nakazom Minfinu Ukrainy vid 09.12.2011 № 1591. [Chart of accounts for accounting of assets, capital, liabilities and business operations of enterprises and organizations: approved. By the order of the Ministry of Finance of Ukraine dated 09.12.2011 № 1591]. (2011, 09.12). (n.d.). zakon.rada.gov.ua. URL: https://zakon.rada.gov.ua/laws/show/z1557-11\#Text [in Ukrainian].

\section{Відомості про автора}

КОВАЛЬ Любов Віталіївна - кандидат економічних наук, доцент кафедри бухгалтерського обліку, Вінницький національний аграрний університет (21008, м. Вінниця, вул. Сонячна, 3, e-mail: kovalstar@ meta.ua).

KOVAL Lubov - Candidate of Economic Sciences, Associate Professor of Accounting Department, Vinnitsa National Agrarian University (21008, Vinnytsia, Soniachna str. 3, e-mail: kovalstar@meta.ua).

КОВАЛЬ Любовь Витальевна - кандидат экономических наук, доцент, кафедры бухгалтерского учета, Винницкий национальный аграрный университет (21008, г. Винница, Солнечная, 3, e-mail: kovalstar@meta.ua). 